\title{
Soil Quality Index Models for Assessing Walnut Orchards in Northern Erbil Province, Iraq
}

\author{
Pakhshan Maulood*, Dalshad Darwesh \\ Environmental Sciences Department, College of Science, Salahaddin University - Erbil, Erbil, Iraq
}

Received: 28 January 2019

Accepted: 22 April 2019

\begin{abstract}
Improving soil quality, sustaining high crop yields and conservation environment are the main goals behind soil quality assessment. Soil quality indexes (SQI) serve as efficient decision tools for agriculture managers, scientists and policy makers to choose appropriate management practices for sustaining land and yield quality. The aim of this study was to evaluate soil quality by using three common SQI models: additive, weighted and principal component analysis (PCA). Seventy-two soil samples were collected during two years (2016 and 2017) from three walnut orchards in Erbil Province, Iraq. SQI values varied from low $(<0.5)$ soil type in location 2 (Malakan village), low $(0.35)$ to moderate $(0.72)$ in location 3 (Choman District) and from low (0.32) to high (0.83) soil type in location 1 (Shaqlawa District). According to weighted SQI, the highest main contribution percentage root growth capacity (RGC) $35 \%$ and the lowest contribution percentage storage water capacity (SWC) 3\% were estimated in the Malakan location. Results indicate that the PCA-SQI model is more convenient for selected soil indicators to minimum data set (MDS) than additive and weighted SQI for evaluating soil quality.
\end{abstract}

Keywords: SQI, walnut orchard, PCA, soil quality type

\section{Introduction}

The soil is a complex ecosystem that forms a thin layer of the earth's crust. It consists of a mixture of minerals, organic matter, water and air, which are essential for growth and maintenance of organisms [1]. Altogether, physical, chemical and biological soil properties estimate soil quality, which is defined as a capacity of soil function in a sustainable way within natural or managed lands to supporting ecosystem services [2-6]. The researchers need to identify and select the most important soil parameters or indicators

*e-mail: pakhshan.maulood@su.edu.krd that reflect the changes in managed land and respond to alteration of natural and anthropogenic activities [7]. Modern studies were focused on choosing, weighting and interpreting sets of physical, chemical and biological indicators to estimate soil function [8]. The most recent study for monitoring soil quality prefers a mathematical equation that has been proposed to combine preferable soil indicators into a model for creating soil quality index (SQI) [9] in order to supply integrated information about soil function and ecosystem services [10]. The SQI is the widest decision-making device used to study agricultural sustainability, soil resource management and socioeconomic viability [11]. Simple additive SQI is easy to apply, after standardization of soil indicators to values between 0 and 1 depending on threshold level, which makes better characterization of soil quality 
[12-14]. While statistical-based model principal component analysis (PCA) initially acts on selecting a minimum data set (MDS) and giving a score for each indicator merged into the index $[5,15]$. However, using PCA or another statistical method has introduced an opportunity for selecting MDS, which allows for avoiding bias and redundancy $[11,16]$.

During our survey, in most walnut orchards in northern Iraq, nearly all agriculture managers and farmers have suffered from a shortage in walnut productivity during the last decade. The reasons may be attributed to a lack of studies on soil quality correlated to nut yield, scarcity of farmers knowledge of their orchards soil quality and agricultural requirements, in addition to the effects of climate change, which cause a dramatic increase in atmospheric temperature and a decrease in the rate of rainfall.

Despite the wide use of SQI to assess soil quality worldwide, since there are no studies about SQI in the studied area for this reason this study aimed to assess the soil quality of walnut orchards in a different area in Erbil governorate by computing three SQI models.

\section{Materials and Methods}

\section{Study Site}

Three areas in the northern part of Erbil Province in Iraq were chosen for this study. Collection of soil samples was done in the following counties with their geographical coordinates using GPS (UTM): Shaqlawa District (38s E0439944 latitude N4028711, elevation $963 \mathrm{~m}$ above sea level ); Malakan village (38s E0463373 N4035073, elevation 1366 above sea level ); and Choman (Warda village) (38s E0489275 N4057261, elevation $1514 \mathrm{~m}$ above sea level) (Fig. 1). The climate of the area is semi-arid characterized by a wet, cold winter (December-March) and hot summer [17].

In each studied area a specific walnut orchard was selected after previously obtained permission from orchard owners. Soil sampling was conducted for two successive years, during June 2016 and 2017. Twelve samples per study orchards were taken from $30-60 \mathrm{~cm}$ depth. All samples were air dried in the laboratory and sieved through a $2 \mathrm{~mm}$ sieve to be used for laboratory analysis.

\section{Laboratory Analysis}

Soil physical, chemical and biological analyses were performed for $2 \mathrm{~mm}$ sieved samples. The following physical and chemical soil properties were determined according to standard methods described by [18]: Bulk density (BD- core method), soil texture (sand, silt and clay- Bouyoucos hydrometer method, field capacity and wilting point (FC and WP) were measured as described by [19], soil $\mathrm{pH}$ and electrical conductivity (EC) were analyzed in soil water suspension using $(1: 2.5 \mathrm{~W} / \mathrm{V})$ potentiometric method and conductivity meter respectively. The calcimeter method was used to determine $\mathrm{CaCO}_{3}$ according to the procedure described by $[14,20]$.

Soil organic matter (SOM- Walkely and Black method), available nitrogen (AvN- Kjeldahl method), available phosphorus (AvP- Olsen method), available

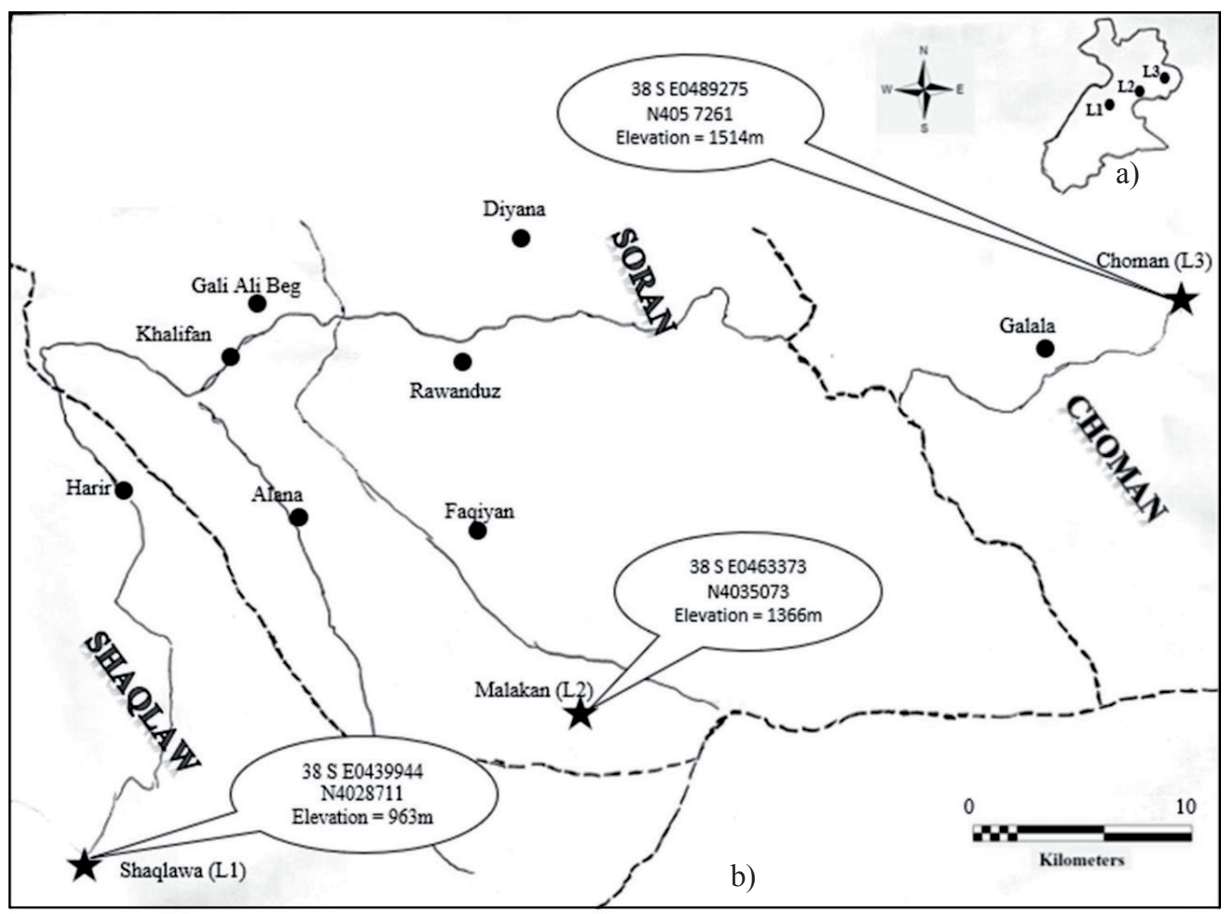

Fig. 1. a) Locations of the studied area in northern part of Erbil province/Iraq and b) study area. 
potassium (AvK- Ammonium acetate extraction method by flame photometer), available calcium and magnesium (AvCa and AvMg- complexometric titration method), and cation exchange capacity (CEC-ammonium acetate extraction method by flame photometer) [18]. Biological properties include: urease activity (UA) measured according to [21, 22], dehydrogenase activity (DA-triphenyl formazan-TPF method) as described by [23], alkaline phosphatase activity (AP- P-nitrophenyl phosphate method) as described by [23], basal soil respiration (BSR- determined as $\mathrm{CO}_{2}$ produced during $120 \mathrm{~h}$ titrimetric method) [24], soil bacterial count (SB- Pour plate count), and soil fungi (SF- spread plate count) were estimated as described by [18].

\section{Soil Quality Index (SQI) Calculation}

\section{Simple Additive SQI}

The simple additive was proposed by [25] for assessing soil quality based on threshold values of soil properties quoted from both literature review and the authors' opinion (Table 1) [10, 15, 26-40]. Then total SQI obtained from the sum of the individual index values [27] as shown in Equation 1:

\section{$\mathrm{SQI}=\sum$ simple soil property index values}

...in which simple SQI of individual soil was calculated by Equation 2:

$$
\text { Simple SQI }=\left(\sum S Q I-S Q I l\right) /(S Q I u-S Q I l)
$$

\section{Weighted SQI}

In this method each soil property was standardized to unit less scoring function between 0 and 1 by applied linear equation [28] based on criteria: 1) (more is better) for an indicator that desirably has higher values (e.g., CEC, SOM, AvN, AvK, FC, DA) (using Equation 3). 2) (less is better) for an indicator that desirably has lower values (e.g., $\mathrm{BD}, \mathrm{CaCO}_{3}, \mathrm{AvCa}, \mathrm{EC}, \mathrm{UA}$ ) (using Equation 4), 3) optimum for such indicators that have a positive influence on soil quality up to a certain level beyond which their influence is detrimental (e.g., pH, AvP, Sand, Silt, Clay, BSR, SB, SF, AP).

$$
\begin{gathered}
\mathrm{A}=\frac{(x-\text { Min.V })}{\operatorname{Max} . V-\text { Min.V }} \\
B=1-\frac{(x-\text { Minthe } . V)}{(\operatorname{Max} . V-\text { Min.V })}
\end{gathered}
$$

Whereas $\mathrm{A}$ and $\mathrm{B}=$ standardized score value: $\mathrm{x}=$ value of soil indicator measured in the field; Min. $\mathrm{V}=$ minimum threshold value; Max. $\mathrm{V}=$ maximum threshold value of soil property.

After obtaining the standardized score for each soil indicator, their weights were proposed depending on soil function according to [41, 42]. Four groups were

\begin{tabular}{|c|c|c|c|}
\hline Soil indicators & $\begin{array}{l}\text { Mini- } \\
\text { mum }\end{array}$ & $\begin{array}{l}\text { Maxi- } \\
\text { mum }\end{array}$ & References \\
\hline $\mathrm{pH}$ & 5.5 & 8.5 & {$[25,26,27]$} \\
\hline $\mathrm{EC}\left(\mu \mathrm{S} . \mathrm{cm}^{-1}\right)$ & 200 & 500 & [27] \\
\hline $\mathrm{BD}\left(\mathrm{g} . \mathrm{cm}^{-3}\right)$ & 1.12 & 1.96 & [28] \\
\hline $\mathrm{FC} \%$ & 20 & 70 & [28] \\
\hline WP\% & 7 & 24 & [29] \\
\hline Sand $\%$ & 45 & 80 & [28] \\
\hline Silt \% & 0 & 28 & [29] \\
\hline Clay $\%$ & 20 & 35 & [29] \\
\hline SOM \% & 0.5 & 5 & [30] \\
\hline $\mathrm{CaCO}_{3} \%$ & 15 & 30 & {$[15]$} \\
\hline $\begin{array}{l}\text { Available Nitrogen } \\
\left(\mathrm{mg} \cdot \mathrm{kg}^{-1}\right)\end{array}$ & 20 & 80 & {$[31]$} \\
\hline $\begin{array}{l}\text { Available Phosphorus } \\
\qquad\left(\mathrm{mg}^{\mathrm{kg}} \mathrm{kg}^{-1}\right)\end{array}$ & 30 & 40 & [31] \\
\hline $\begin{array}{l}\text { Available Potassium } \\
\qquad\left(\mathrm{mg} \cdot \mathrm{kg}^{-1}\right)\end{array}$ & 100 & 150 & [31] \\
\hline $\begin{array}{l}\text { Available Calcium } \\
\left(\mathrm{mg} \cdot \mathrm{kg}^{-1}\right)\end{array}$ & 100 & 2000 & [31] \\
\hline $\begin{array}{l}\text { Available Magnesium } \\
\qquad\left(\mathrm{mg} \cdot \mathrm{kg}^{-1}\right)\end{array}$ & 100 & 250 & [31] \\
\hline CEC (Cmole.kg $\left.{ }^{-1}\right)$ & $\leq 10$ & $\geq 18$ & [30] \\
\hline $\begin{array}{l}\text { Soil Respiration } \mu \mathrm{g} \mathrm{CO}_{2^{-}} \\
\mathrm{C} / \mathrm{g} \text { DW per (120 hour) }\end{array}$ & 35.84 & 71.68 & {$[32]$} \\
\hline $\begin{array}{l}\text { Bacterial count } \\
\left(\mathrm{CFU} \cdot \mathrm{g} * 10^{-3}\right)\end{array}$ & $4 * 10^{6}$ & $2 * 10^{9}$ & [33] \\
\hline Fungal count $\left(\mathrm{CFU} . \mathrm{g}^{*} 10^{-2}\right)$ & $10^{3}$ & $10^{4}$ & {$[34]$} \\
\hline Urease $\left(\mu \mathrm{g} \cdot \mathrm{g}^{-1}\right.$ dry soil. $\left.\mathrm{hr}^{-1}\right)$ & 0.5 & $\begin{array}{c}10(10- \\
16)\end{array}$ & {$[35,36,37]$} \\
\hline $\begin{array}{l}\text { Alkaline Phosphatase } \\
\qquad\left(\mu \mathrm{g} \cdot \mathrm{g}^{-1} \cdot \mathrm{hr}^{-1}\right)\end{array}$ & 40 & 110 & {$[38,39]$} \\
\hline $\begin{array}{l}\text { Dehydrogenase } \mu \mathrm{g} \text { TPF } \\
\mathrm{g}^{-1} \text { soil }\end{array}$ & 10 & 40 & [40] \\
\hline
\end{tabular}

Table 1. Minimum and maximum limits for standardization of evaluated indicators.

established: root growth capacity (RGC, e.g., BD, Texture, $\mathrm{AvCa}, \mathrm{CaCO}_{3}$ ), plant nutrient supply (PNS, e.g., pH, EC, AvN, AvP, AvK, AvMg, CEC), biological activity (BA, e.g., enzymes activity, BSR, SB, SF), and storage water capacity (SWC, e.g., FC). Each soil function was assigned numerical weights according to their importance for improving and maintaining soil quality (Table 2). Some studies have suggested the same weight of 0.25 for each function considering that all functions are important [43], whereas other studies suggested more weight for function represented by higher indicators [42]. In this study, we prefer the last suggestion and give 0.3 weight for each PNS and BA functions, while RGC and SWC take 0.2 weight, the sum 
Table 2. Weighted SQI model (adopted from [27]).

\begin{tabular}{|c|c|c|c|c|c|c|c|c|c|}
\hline Soil functions & Weight (A) & Soil indicators & Sub-weight (B) & Score (C) & $\mathrm{B}^{*} \mathrm{C}$ & $\sum \mathrm{B}^{*} \mathrm{C}=\mathrm{D}$ & $\mathrm{D}^{*} \mathrm{~A}$ & $\%$ & SQI \\
\hline \multirow[t]{3}{*}{ RGC } & & $\mathrm{BD}$ & 0.4 & 0.94 & 0.37 & 0.59 & 0.12 & 36 & 0.32 \\
\hline & 0.2 & Texture & 0.4 & 0.48 & 0.19 & & & & \\
\hline & & $\mathrm{CaCO}_{3}$ & 0.2 & 0.11 & 0.02 & & & & \\
\hline \multirow[t]{9}{*}{ PNS } & & $\mathrm{pH}$ & 0.1 & 0.74 & 0.07 & 0.32 & 0.10 & 29 & \\
\hline & & $\mathrm{EC}$ & 0.1 & 0.39 & 0.04 & & & & \\
\hline & & $\mathrm{AvN}$ & 0.1 & 0.04 & 0.00 & & & & \\
\hline & & $\mathrm{AvP}$ & 0.1 & 0.16 & 0.02 & & & & \\
\hline & 0.3 & AvK & 0.1 & 0.53 & 0.05 & & & & \\
\hline & & $\mathrm{AvCa}$ & 0.05 & 0.56 & 0.03 & & & & \\
\hline & & $\mathrm{AvMg}$ & 0.05 & 0.55 & 0.03 & & & & \\
\hline & & CEC & 0.2 & 0.20 & 0.04 & & & & \\
\hline & & SOM & 0.2 & 0.18 & 0.04 & & & & \\
\hline \multirow[t]{7}{*}{ BA } & & UA & 0.2 & 0.40 & 0.08 & 0.34 & 0.10 & 32 & \\
\hline & & $\mathrm{AP}$ & 0.2 & 0.23 & 0.05 & & & & \\
\hline & & DA & 0.2 & 0.63 & 0.13 & & & & \\
\hline & 0.3 & SB & 0.1 & 0.08 & 0.01 & & & & \\
\hline & & SF & 0.1 & 0.30 & 0.03 & & & & \\
\hline & & BSR & 0.1 & 0.34 & 0.03 & & & & \\
\hline & & SOM & 0.1 & 0.18 & 0.02 & & & & \\
\hline SWC & 0.2 & $\mathrm{FC}$ & 1 & 0.042 & 0.042 & 0.042 & 0.01 & 3 & \\
\hline
\end{tabular}

RGC, root growth capacity. PNS, plant nutrients supply. BA, biological activity. SWC, storage water capacity. SQI, soil quality index. All other abbreviations as in Table 3.

of all function must be 1 . Thereafter, each indicator was taken at their sub-weight according to their importance under particular soil function properties [27]. Weighted SQI was computed by (Equation 5):

$$
\text { Weighted } S Q I=\Sigma(W * S f)
$$

..where $\mathrm{W}=$ assigned weight and $\mathrm{Sf}=$ soil function.

\section{Statistical Factor Analysis}

\section{(Principal Component Analysis) SQI}

PCA is a statistical method used by different researchers to estimate SQI [5, 13, 14, 27, 28, 44]. The PCA is a common tool to extract information and reduce data to choose the most important indicator in a minimum data set (MDS) [11, 27]. The PCs (principal components) with eigenvalues more than $>1$ were selected. Within each chosen PC, the variables with the highest eigenvectors were taken (factors that have loading values within $10 \%$ of the highest value) in MDS. However, Pearsons correlation coefficient was used to reduce redundancy of data for a retained variable within selected PCs. If the retained variable correlated, only the variable with the highest eigenvector was selected, and others will be eliminated, while with non-correlated relation each of it considered as important variable and chosen in MDS for calculating SQI. To obtain weight value $(\mathrm{Wi})$ for each $\mathrm{PC}$, the certain percentage variation of $\mathrm{PC}$ is divided by the total percentage variation explained by all the PCs selected for MDS with eigenvalue $>1$. Then, SQI was estimated from Equation 6 [13]:

$$
S Q I=\sum_{i=1}^{n} W i * S i
$$

...where $\mathrm{Wi}=$ is the PCA weighting factor, $\mathrm{Si}=$ is the indicator score for each variable $\mathrm{I}$, and $\mathrm{n}$ is the number of variables in the MDS.

\section{Statistical Analysis}

Statistical analysis of the data was performed using the SPSS (Statistical Package for Social ScienceVersion 22) program and Microsoft Office Excel 2010. 
Table 3. Descriptive statistics of all soil indicators for studied locations during two years (2016 and 2017).

\begin{tabular}{|c|c|c|c|c|c|c|c|c|c|c|c|c|}
\hline \multirow[b]{3}{*}{ Soil properties } & \multicolumn{6}{|c|}{2016} & \multicolumn{6}{|c|}{2017} \\
\hline & \multicolumn{2}{|c|}{ L1 } & \multicolumn{2}{|c|}{$\mathrm{L} 2$} & \multicolumn{2}{|c|}{ L3 } & \multicolumn{2}{|c|}{$\mathrm{L} 1$} & \multicolumn{2}{|c|}{ L2 } & \multicolumn{2}{|c|}{ L3 } \\
\hline & Mean & SD & Mean & SD & Mean & SD & Mean & SD & Mean & SD & Mean & SD \\
\hline $\mathrm{BD}\left(\mathrm{g}^{\mathrm{cm}} \mathrm{cm}^{-3}\right)$ & 0.958 & 0.039 & 1.113 & 0.054 & 1.071 & 0.090 & 0.981 & 0.073 & 1.111 & 0.043 & 1.044 & 0.103 \\
\hline Sand $\%$ & 15.61 & 4.378 & 3.613 & 2.031 & 14.41 & 6.796 & 15.61 & 4.378 & 3.613 & 2.031 & 14.41 & 6.796 \\
\hline Silt \% & 43.81 & 14.05 & 74.15 & 5.267 & 52.25 & 17.60 & 43.81 & 14.05 & 74.15 & 5.267 & 52.25 & 17.60 \\
\hline Clay \% & 40.57 & 12.63 & 22.24 & 3.445 & 33.33 & 11.72 & 40.57 & 12.63 & 22.24 & 3.445 & 33.33 & 11.72 \\
\hline FC \% & 29.38 & 5.014 & 22.11 & 1.368 & 27.33 & 4.158 & 29.38 & 5.021 & 22.05 & 1.365 & 27.28 & 4.190 \\
\hline WP \% & 18.77 & 4.420 & 12.35 & 1.206 & 16.95 & 3.666 & 18.77 & 4.419 & 12.35 & 1.200 & 16.94 & 3.662 \\
\hline $\mathrm{pH}$ & 7.908 & 0.075 & 7.731 & 0.145 & 7.713 & 0.069 & 8.334 & 0.108 & 8.235 & 0.113 & 8.399 & 0.126 \\
\hline $\mathrm{EC}\left(\mu \mathrm{S} . \mathrm{cm}^{-1}\right)$ & 592.4 & 195.6 & 493.4 & 131.0 & 667.8 & 298.5 & 436.5 & 85.95 & 531.2 & 148.9 & 463.9 & 94.94 \\
\hline SOM \% & 1.807 & 0.406 & 1.324 & 0.221 & 1.499 & 0.467 & 1.821 & 0.744 & 1.562 & 0.239 & 2.157 & 0.771 \\
\hline Av N (mg.kg $\left.{ }^{-1}\right)$ & 228.3 & 2.591 & 226.4 & 5.238 & 223.8 & 7.402 & 228 & 6.134 & 231.8 & 3.906 & 227.9 & 2.879 \\
\hline Av P (mg.kg $\left.g^{-1}\right)$ & 10.29 & 3.034 & 7.894 & 5.566 & 12.98 & 4.432 & 10.25 & 2.31 & 8.88 & 3.460 & 10.23 & 4.04 \\
\hline Av K (mg.kg $\left.{ }^{-1}\right)$ & 34.77 & 7.402 & 20.62 & 2.862 & 53.94 & 19.25 & 81.07 & 17.81 & 43.92 & 8.929 & 105.4 & 48.62 \\
\hline $\mathrm{Av} \mathrm{Ca}\left(\mathrm{mg} \cdot \mathrm{kg}^{-1}\right)$ & 5267 & 1435 & 3600 & 639.6 & 4450 & 648.8 & 3100 & 705.8 & 2275 & 580.2 & 2367 & 407.5 \\
\hline $\mathrm{Av} \mathrm{Mg}\left(\mathrm{mg} \cdot \mathrm{kg}^{-1}\right)$ & 5770 & 2148 & 9420 & 3091 & 9285 & 1165 & 1480 & 500.9 & 780.0 & 418.0 & 805.0 & 486.4 \\
\hline CEC (Cmole.kg $\left.{ }^{-1}\right)$ & 11.27 & 2.391 & 14.51 & 15.93 & 24.02 & 10.56 & 25.43 & 3.522 & 38.18 & 4.080 & 6.799 & 3.213 \\
\hline $\mathrm{CaCO}_{3} \%$ & 36.92 & 2.202 & 1.653 & 0.992 & 0.218 & 0.267 & 37.15 & 3.154 & 0.553 & 0.599 & 1.279 & 1.451 \\
\hline UA ( $\mu$ g.g dry soil.hr $\left.{ }^{-1}\right)$ & 89.78 & 27.49 & 59.74 & 30.80 & 59.68 & 26.90 & 112.4 & 60.10 & 52.52 & 36.93 & 96.74 & 40.86 \\
\hline DA ( $\mu$ g TPF $g^{-1}$ soil $)$ & 108.3 & 38.17 & 93.43 & 40.00 & 111.5 & 32.69 & 39.87 & 3.536 & 43.49 & 12.65 & 66.66 & 43.95 \\
\hline AP $\left(\mu \mathrm{g} \cdot g-1 . h r^{-1}\right)$ & 52.14 & 5.791 & 60.95 & 13.13 & 52.504 & 3.482 & 146.3 & 28.52 & 95.60 & 53.58 & 195.42 & 67.96 \\
\hline $\begin{array}{c}\mathrm{BSR} \mu \mathrm{g} \mathrm{CO}_{2}-\mathrm{C} / \mathrm{g} \mathrm{DW} \\
\text { per hr. }\end{array}$ & 117.8 & 42.24 & 93.13 & 56.32 & 129.8 & 43.98 & 106.9 & 34.00 & 80.53 & 44.63 & 113.11 & 39.96 \\
\hline SB (CFU. g * $10^{-3}$ ) & 1014 & 1662 & 1841 & 1677.2 & 2251 & 2872 & 165.1 & 197.5 & 130.3 & 51.53 & 5330 & 6281 \\
\hline SF (CFU. g* $\left.10^{-2}\right)$ & 72.74 & 100.9 & 95.92 & 148.7 & 171.0 & 60.65 & 1.651 & 1.975 & 72.69 & 161.1 & 573.1 & 639.8 \\
\hline
\end{tabular}

BD, bulk density FC, field capacity. WP, wilting point. EC, electrical conductivity. SOM, soil organic matter. AvN, available nitrogen. AvP, available phosphorus Av K, available potassium. Av Ca, available calcium. Av Mg, available magnesium. CEC, cation exchange capacity. $\mathrm{CaCO}_{3}$, calcium carbonate. UA, urease enzyme activity. DA, dehydrogenase enzyme activity. AP, alkaline phosphatase enzyme activity. BSR, basal soil respiration, SB, soil bacteria number. SF, soil fungi number. SD, standard deviation.

Descriptive statistics were carried out and all values are presents as means \pm standard deviations (SD) for laboratory measurements. PCA was applied to retained indicators for (MDS). Correlation was evaluated for significance using a Pearson correlation coefficient test procedure. A $\mathrm{P} \leq 0.01$ was considered to be statistically significant.

\section{Results and Discussion}

The mean and standard deviation (SD) values for all laboratory analysis soil indicators are summarized in Table 3. The results of bulk density (BD) in the studied locations was lower than the minimum level $\left(1.12 \mathrm{~g} . \mathrm{cm}^{-3}\right)$ and classified as an optimum value [28]. Good soil porosity, soil aggregate, and aeration was obtained from low soil BD [44]. However, differences in soil texture were found from sand clay in location 1 to the sandy clay loam in two other locations. Higher clay content in location 1 indicated more ability to water, and organic matter retained, and also higher CEC value and nutrients retained [5]. The soil is slightly alkaline with $\mathrm{pH} \mathrm{H}_{2} \mathrm{O}$ above 7.7, also relatively higher $\mathrm{pH}_{2} \mathrm{O}$ values of about 8.2 recorded in all locations during the second year of sampling. It might also come from alkaline calcareous nature of parent rock, and the above soil corresponded with a higher amount of ion bases [45]. On the other hand, high soil $\mathrm{pH} \mathrm{H}_{2} \mathrm{O}$ could cause phosphorus deficiencies $\left(\mathrm{P}<15 \mathrm{mg} . \mathrm{Kg}^{-1}\right)$ and reduce their 


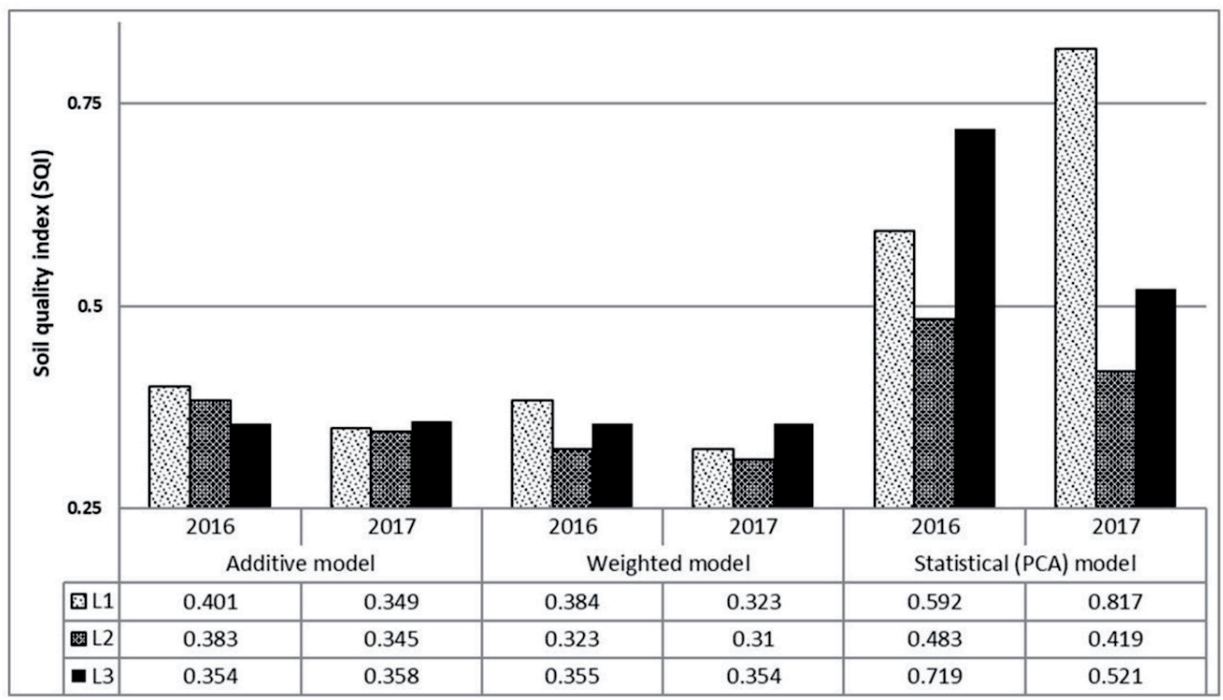

Fig. 2. Overall soil quality index (SQI) values for different soil types.

availability for plants. The same inverse relationship between AvP and soil $\mathrm{pH} \mathrm{H}_{2} \mathrm{O}$ was found by [46]. The EC values in all studied locations were lower than those reported by [47] salinity hazard levels for cultivated plants.

SOM is a principal soil indicator that influences other physical, chemical and biological soil properties. [2] has reported that organic matter positively affects and improves other soil parameters, including CEC, water content, nutrient availability, microorganism activity and reduced soil erosion. Soil organic content is relatively low in location $2(<1 \%)$ to moderate content in the other two locations $(>1 \%)$. However, the lower SOM content in the study area might be explained by rapid mineralization of organic matter that was enhanced by favourable climate factor conditions. The same results were found and explained by [3]. AvK ranged from the highest concentration in location 3 to the lowest concentration in location 2 . It could be related to low
SOM in location 2, which plays a key role in nutrients cycling and availability of $\mathrm{K}^{+}$in soil $[2,48]$. CEC of the studied soils varied from $11.26 \mathrm{Cmole} . \mathrm{Kg}^{-1}$ in location 1 to 38.17 Cmole. $\mathrm{Kg}^{-1}$ in location 2. It ranged from moderate to high CEC values. Akhtaruzzaman et al. [49] stated that CEC value was mainly related to soil texture, organic matter accumulation and amount and types of clay minerals.

Basal soil respiration (BSR) rate was high in all studied soils, which might be attributed to high and faster biological activities than organic matter decomposition, and it can be able to plant nutrient supply. Our findings are in agreement with the results of [44], although lower BSR values were measured in location 2, which coincided with the lowest content of SOM, AvP, AvK, AvCa and DA.

Soil enzymes are among the essential soil parameters related to the nutrient cycle in nature which reflects microbial activities in the soil $[24,50]$ and acts as soil

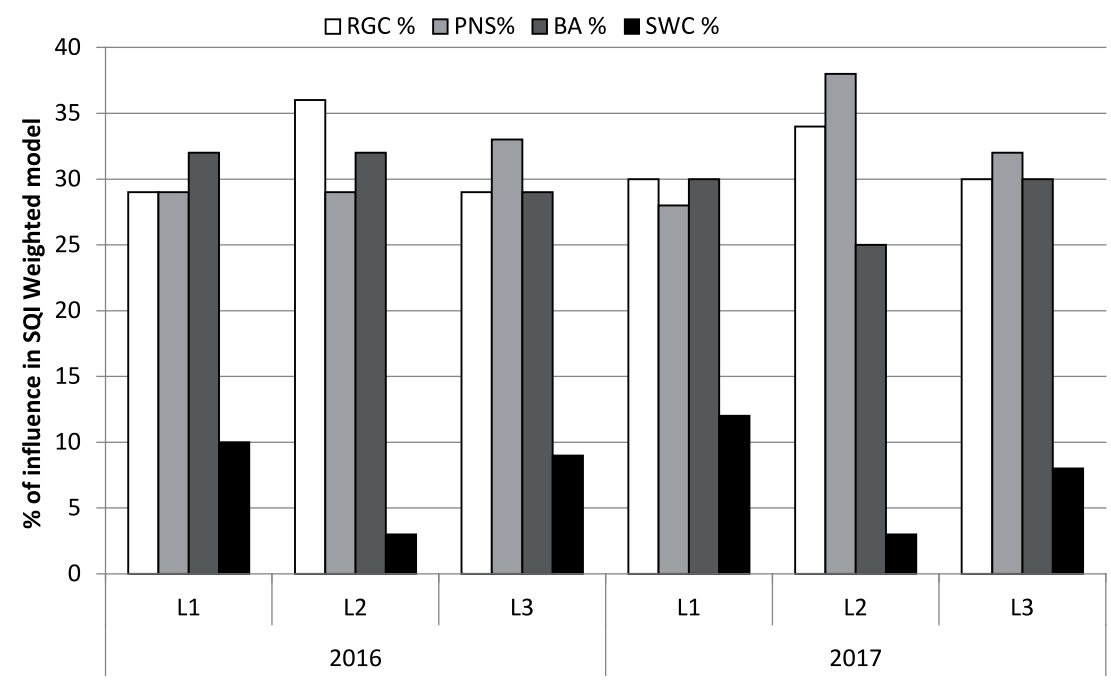

Fig. 3. Percentage contribution of each soil function in weighted SQI model in different locations during studied period. 
Table 4. Eigenvector and percentage of variance explained by each of the seven principal components (PCs).

\begin{tabular}{|c|c|c|c|c|c|c|c|c|}
\hline & $\mathrm{PC} 1$ & $\mathrm{PC} 2$ & $\mathrm{PC} 3$ & $\mathrm{PC} 4$ & PC5 & PC6 & $\mathrm{PC7}$ & \\
\hline Eigenvalues & 7.163 & 4.203 & 2.996 & 2.407 & 2.201 & 1.396 & 1.009 & \\
\hline$\%$ of variance & 31.142 & 18.276 & 13.025 & 10.464 & 9.571 & 6.071 & 4.388 & \\
\hline Cumulative \% & 31.142 & 49.418 & 62.443 & 72.906 & 82.478 & 88.549 & 92.937 & \\
\hline Indicators & \multicolumn{7}{|c|}{ Eigenvectors } & Communalities \\
\hline $\mathrm{BD}$ & -0.085 & 0.326 & 0.196 & -0.455 & 0.107 & 0.419 & 0.670 & 0.995 \\
\hline Sand & $\underline{0.847}$ & -0.130 & 0.395 & -0.031 & -0.124 & 0.019 & -0.040 & 0.911 \\
\hline Silt & -0.681 & 0.047 & -0.619 & -0.186 & -0.222 & 0.076 & -0.060 & 0.943 \\
\hline Clay & 0.184 & -0.260 & 0.900 & -0.140 & -0.092 & -0.121 & -0.090 & 0.963 \\
\hline $\mathrm{FC}$ & 0.072 & -0.955 & -0.062 & 0.017 & -0.112 & -0.189 & 0.026 & 0.970 \\
\hline WP & -0.072 & $\underline{0.955}$ & 0.062 & -0.017 & 0.112 & 0.189 & -0.026 & 0.970 \\
\hline $\mathrm{pH}$ & -0.727 & -0.035 & -0.240 & 0.444 & -0.222 & 0.008 & 0.396 & 0.991 \\
\hline $\mathrm{EC}$ & 0.151 & 0.315 & 0.808 & -0.083 & 0.323 & 0.076 & -0.050 & 0.894 \\
\hline SOM & 0.806 & 0.084 & 0.268 & 0.160 & 0.083 & 0.234 & -0.178 & 0.847 \\
\hline AvN & -0.628 & -0.213 & -0.373 & 0.450 & 0.194 & 0.170 & -0.252 & 0.912 \\
\hline $\mathrm{AvP}$ & 0.374 & -0.026 & 0.455 & 0.027 & 0.761 & 0.014 & 0.100 & 0.939 \\
\hline AvK & -0.838 & 0.152 & 0.187 & 0.130 & -0.155 & 0.197 & 0.262 & 0.909 \\
\hline $\mathrm{AvCa}$ & 0.479 & -0.124 & 0.388 & 0.101 & 0.534 & 0.522 & 0.073 & 0.969 \\
\hline $\mathrm{AvMg}$ & -0.006 & -0.219 & 0.063 & 0.031 & -0.899 & 0.104 & 0.243 & 0.930 \\
\hline CEC & 0.228 & $\underline{0.881}$ & -0.198 & -0.149 & -0.081 & -0.152 & 0.098 & 0.929 \\
\hline $\mathrm{CaCO}_{3}$ & -0.021 & -0.240 & -0.073 & 0.744 & 0.292 & -0.297 & -0.045 & 0.793 \\
\hline UA & 0.312 & -0.128 & 0.015 & -0.542 & -0.016 & -0.724 & -0.033 & 0.933 \\
\hline DA & -0.417 & -0.113 & -0.203 & 0.147 & -0.201 & 0.080 & $\underline{0.824}$ & 0.975 \\
\hline AP & -0.112 & -0.328 & 0.189 & 0.061 & 0.261 & -0.770 & -0.158 & 0.846 \\
\hline BSR & 0.829 & 0.413 & -0.052 & 0.037 & 0.148 & -0.304 & -0.048 & 0.980 \\
\hline SB & 0.121 & 0.095 & 0.019 & $\underline{0.879}$ & -0.181 & 0.256 & 0.046 & 0.898 \\
\hline SF & -0.386 & -0.104 & 0.017 & -0.186 & 0.517 & 0.665 & 0.096 & 0.914 \\
\hline
\end{tabular}

PC, principal component. All other abbreviations as in Table 3.

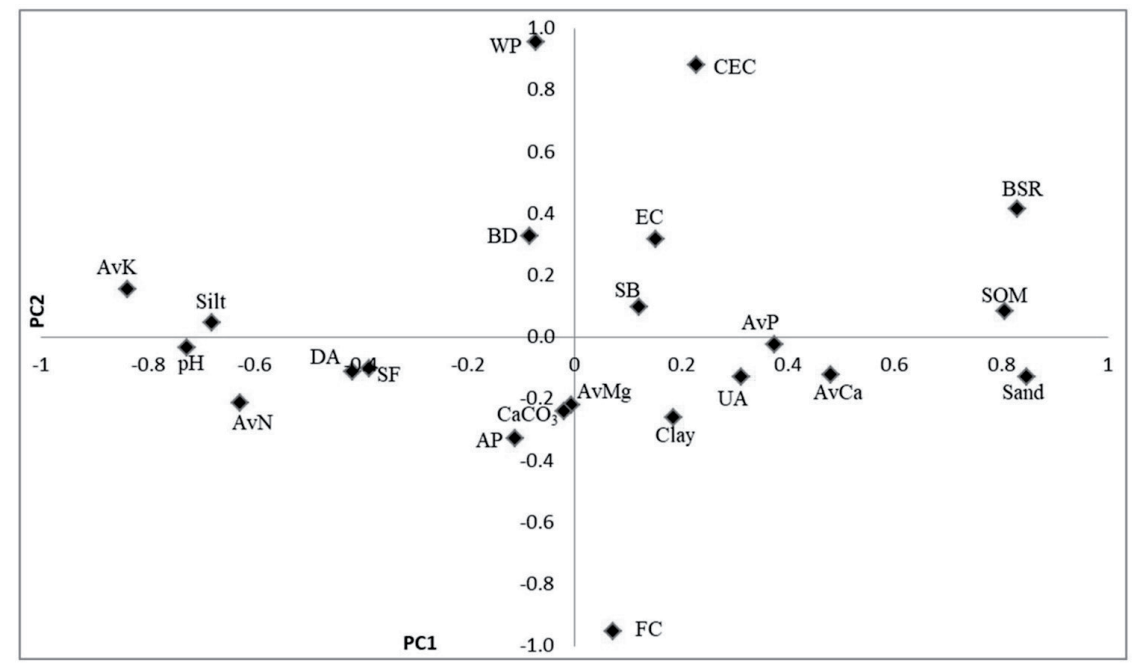

Fig. 4. Principal component analysis (PCA) scatterplot for soil indicators. 


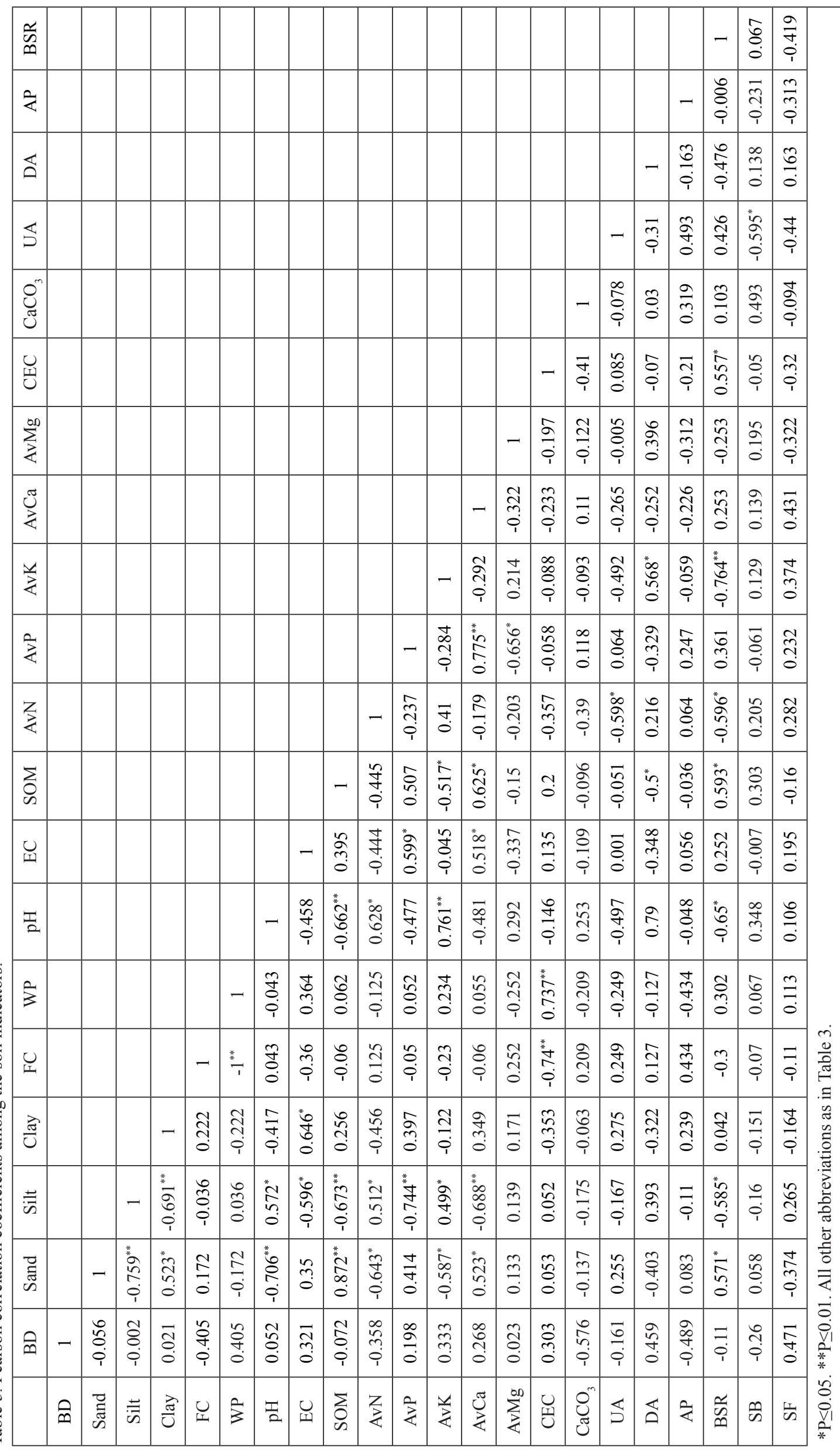


fertility indicators [51]. Alkaline phosphatase (AP) activity showed higher values in all studied locations during the second year of sampling. This might be due to the high $\mathrm{pH} \mathrm{H}_{2} \mathrm{O}$ values in the same time with lowest phosphorus availability. Our results are in agreement with that revealed by [52], who reported alkaline phosphatase function to be under $\mathrm{pH}_{2} \mathrm{O}$ optimum level (8.5-11) for its activity. Generally, enzyme activity in location 3 was higher than the other two locations, which could be due to the soil texture and organic matter content that provide good aeration and nutrient availability for microorganism activity.

\section{Soil Quality Index (SQI)}

The SQI for the studied walnut orchard was variable (Fig. 2). Depending on additive SQI values, all soil qualities were classified as low type, with the highest value $(0.4)$ recorded in location 1 to the lowest value (0.34) observed in location 2 during 2017. Generally, soil type was more affected by the soil quality of the locations.

The composition of weighted SQI exhibited in (Fig. 3), in which RGC had the main contribution in all studied locations with percentage value ranging $29-36 \%$; PNS ranged $28-38 \%$ and BA ranged $25-32 \%$, while SWC had the lowest percentage of influence value and ranged $3-12 \%$. The highest and lowest percentage effects for RGC and SWC, respectively were found in location 2 compared to other studied locations. These results have a reflection effect on SQI value for location 2 with the lowest value $(0.31)$ compared to the highest value (0.38) in location 1. According to these values, all soil types are classified as a low soil type or class. Thus, the results might be due to the contribution of all soil indicators for computing the first two SQI models in which some of the indicators are not essential for such soil management. In addition to scoring indicators from the literature review and authors opinion make it less accurate than SQI PCA model.

In the SQI PCA model, all soil variables in the studied locations were included in the PCA statistical programmer SPSS 22. Retained PCs with eigenvalue $>1$ that represented the greatest variability in the data set consists of the first seven PCs, and it explained by $92.9 \%$ of the variation (Table 4, Fig. 4). Under each PC, the variables with high eigenvector value were retained for MDS (boldfaced value). After that, the highly weighted values for PC1 were: sand, pH, SOM, AvK and BSR. For PC2 each of FC, WP and CEC were highly weighted. While PC3 was represented by clay and EC. Under $\mathrm{PC} 4, \mathrm{SB}$ and $\mathrm{CaCO}_{3}$ were highly weighted. Meanwhile, PC5 (both AvMg and AvP) were selected. PC6 retained enzymes UA and AP, whereas PC7 was represented by DA. Then, for selecting indicators for each PC for MDS, they were subjected to the Pearson correlation coefficient test. When retained variables correlated, only the highest eigenvector weight selected and others that were eliminated, while the non-correlated indicator for each PC was considered as important and retained for MDS. Thus, results in Table 5 show a highly significant correlation $(\mathrm{P} \leq 0.01)$ between sand and each of $\mathrm{pH}$ $\mathrm{H}_{2} \mathrm{O}$ and SOM with the correlation coefficient values of (-0.706 and 0.872 respectively), while a significant correlation $(\mathrm{P} \leq 0.05)$ was recorded between sand and each of AvK with the correlation coefficient values of $(-0.587)$ and BSR (0.571) respectively. Also, significant correlation was found between the obtained indicators in PC2, PC3, PC5 and PC7. So, in these PCs only the highest eigenvector values were retained: $\mathrm{PC} 1=$ sand, PC2 $=\mathrm{WP}, \mathrm{PC} 3=$ clay, PC5 $=\mathrm{AvMg}$, and PC7 = DA. Meanwhile, in PC4 no significant correlation was found between BSR and $\mathrm{CaCO}_{3}$. Whereas in PC6 also no significant correlation between AP and UA was observed. Therefore, the obtained quality index method is influenced by (boldface italic values): sand $>\mathrm{WP}>$ clay $>\mathrm{SB}=\mathrm{CaCO}_{3}>\mathrm{AvMg}>\mathrm{AP}=\mathrm{UA}>\mathrm{DA}$, and will be used in SQI calculation.

The interpretation of selected PCs is important to understand the process that takes place for better management. PC1 and PC3 represented plant nutrient retention and supply for supporting productivity, while PC2 might be interpreted for water retention and nutrient supply. However, PC4 represented biotic activity for sustaining productivity. Meanwhile, PC5 corresponds to plant nutrient supply. In the case of PC6 and PC7 this could be explained for biotic activity and plant nutrient supply for sustaining productivity [2, 3, 9]. Despite this, results of PCA SQI values the soil quality of location 2 still classified as the low type with values $(0.48$ and 0.49 respectively) for both studied years. The soil quality in location 3 was classified as moderate type ( 0.72 and 0.52 respectively) for the sampling period 2016-2017. It is mostly related to soil type of location 1 (sand clay) and high content of SOM and water content. Then results could encourage farmers and agriculture managers to improve soil quality of walnut orchards through increasing organic matter content, which improves the plant nutrients supply, water content and reduced root penetration resistance of managed soil.

\section{Conclusions}

The soil quality assessment of different walnut orchards using three SQI models revealed that SOM influences soil type through improving soil physical, chemical and biology indicators. Low nutrient availability might be one of the major reasons behind the lack of walnut productivity. Increases in alkaline phosphatase activity coincided with high $\mathrm{pH}_{2} \mathrm{O}$ values. SQI values of three models classified soil quality of location 2 as low type. While it varied from moderate to high type in location 1 and as the moderate type for location 3, depending on SQI PCA values. The low type soil quality of location 2 showed the highest effect percentage of RGC and the lowest for SWC, which might be attributed to soil texture, relatively 
high BD, and lower SOM, FC, AvK, and AvP contents. Generally, the SQI PCA model is considered as a most appropriate method. Furthermore, in order to evaluate the effectiveness of SQI to assess soil quality, it could be correlated to walnut yield to recognize the best farm management and conservation.

\section{Acknowledgements}

Authors would like to thank owners of walnut orchards to permit taking soil samples, also to villagers for their hospitality. Finally, we are grateful to Dr. Yahya A. Shekha in the Environmental Sciences Department/ College of Science/ Salahaddin University- Erbil for allowing us to use his laboratory for soil analysis.

\section{Conflict of Interest}

There is no conflict of interest among the authors.

\section{References}

1. STEFANOSKI D.C., FIGUEIREDO C.C., SANTOS G.G., MARCHAO R.L. Selecting soil quality indicators for different soil management systems in the Brazilian Cerrado. Pesquisa Agropecuária Brasileira, 51 (9), 1643, 2016.

2. ADEYOLANU O.D., OGUNKUNLE A.O. Comparison of qualitative and quantitative approaches to soil quality assessment for agricultural purposes in South-western Nigeria. Cogent Food \& Agriculture, 2 (1), 1149914, 2016.

3. GLOVER J., REGANOLD J., ANDREWS P. Systematic method for rating soil quality of conventional, organic, and integrated apple orchards in Washington State. Agriculture, Ecosystems \& Environment, 80 (1-2), 29, 2000.

4. MORUGAN-CORONADO A., ARCENEGUI V., GARCIA-ORENES F., MATAIX-SOLERA J., MATAIXBENEYTO J. Application of soil quality indices to assess the status of agricultural soils irrigated with treated wastewaters. Solid Earth, 4 (1), 119, 2013.

5. PAZ-KAGAN T., SHACHAZ M., ZAADY E., KARNIELI A. A spectral soil quality index (SSQI) for characterizing soil function in areas of changed land use. Geoderma, 230, 171, 2014

6. WIENHOLD B.J., ANDREWS S., KARLEN D. Soil quality: a review of the science and experiences in the USA. Environmental Geochemistry and Health, 26 (2), 89, 2004.

7. KALAMBUKATTU J.G., KUMAR S., GHOTEKAR Y.S. Spatial variability analysis of soil quality parameters in a watershed of Sub-Himalayan Landscape-A case study. Eurasian Journal of Soil Science, 7 (3), 238, 2018.

8. ALVES DE CASTRO LOPES A., GOMES DE SOUSA D.M., CHAER G.M., BUENO DOS REIS JUNIOR F., GOEDERT W.J., DE CARVALHO M. I. Interpretation of microbial soil indicators as a function of crop yield and organic carbon. Soil Science Society of America Journal, 77 (2), 461, 2013.
9. GELAW A.M., SINGH B.R., LAI R. Soil quality indices for evaluating smallholder agricultural land uses in northern Ethiopia. Sustainability, 7 (3), 2322, 2015.

10. SINGH A., BORDOLOI L., KUMAR M., HAZARIKA S., PARMAR B. Land use impact on soil quality in eastern Himalayan region of India. Environmental Monitoring and Assessment, 186 (4), 2013, 2014.

11. ANDREWS S.S., KARLEN D., MITCHELL J. A comparison of soil quality indexing methods for vegetable production systems in Northern California. Agriculture, Ecosystems \& Environment, 90 (1), 25, 2002.

12. KARLEN D.L., STOTT D.E. A framework for evaluating physical and chemical indicators of soil quality. Defining Soil Quality for a Sustainable Environment: 53, 1994.

13. SUPRIYADI S., HARTATI S., MACHFIROH N. Soil Quality Index in the Upstream of Bengawan Solo River Basin According to the Soil Function in Nutrient Cycling Based on Soybean Production in Agroforestry. AGRIVITA, Journal of Agricultural Science, 38 (1), 55, 2016.

14. FILEP T., DRASKOVITS E., SZABO J., KOOS S., LASZLO P. The dissolved organic matter as a potential soil quality indicator in arable soils of Hungary. Environmental Monitoring and Assessment, 187 (7), 479, 2015.

15. ELBASIOUNY H., ELBEHIRY F., ABOWALY M. Soil Quality Indices-Special Focus on Salt-Affected Soil: Review and Case Study in Northern Egypt. Env. Biodiv. Soil Secur., 1, 85, 2017.

16. ASKARI M.S., HOLDEN N.M. Quantitative soil quality indexing of temperate arable management systems. Soil and Tillage Research, 150, 57, 2015.

17. AL-KUBAISI Q.Y., GARDI L.M. Dust storm in Erbil city as a result of climatic change in Kurdistan Region Iraq. Iraqi Journal of Science, 53, 40, 2012.

18. BARUAH T.C., BARTHAKUR H.P. A text book of soil analysis. Vikas Publishing House PVT LTD, India, 334, 2001.

19. KARIM T. Models to predict water retention of Iraqi soils. Journal of the Indian Society of Soil Science (India), 1999.

20. LOEPPERT R.H., SUAREZ D.L. Carbonate and gypsum. Publications from USDA-ARS / UNL Faculty. 504. http:// digitalcommons.unl.edu/usdaarsfacpub/504, 1996.

21. AKMAL M., ALTAF M., HAYAT R., HASSAN F., ISLAM M. Temporal changes in soil urease, alkaline phosphatase and dehydrogenase activity in rainfed wheat field of Pakistan. Journal of Animal and Plant Science, 22 (2), 457, 2012.

22. WANG W., PAGE-DUMROESE D., LV R., XIAO C., LI G. Soil enzyme activities in pinus tabuliformis (Carriére) plantations in Northern China. Forests, 7 (2), 112, 2016.

23. ALOTAIBI K.D., SCHOENAU J.J. Enzymatic activity and microbial biomass in soil amended with biofuel production byproducts. Applied Soil Ecology, 48 (2), 227, 2011.

24. CHENG F., PENG X., ZHAO P., YUAN J., ZHONG C. Soil microbial biomass, basal respiration and enzyme activity of main forest types in the Qinling Mountains. PLoS One, 8 (2), e67353, 2013.

25. AMACHER M.C., O’NEIL K.P., PERRY C.H. Soil vital signs: a new soil quality index (SQI) for assessing forest soil health. USDA Forest Service Res. Pap, 65, 2007.

26. MENDEZ J.P., GARCIA F.P., SANDOVAL O.A.A., MARZO M.A.M. Indicators and Quality Indices of Soil (QIS) Producer's Barley in the Southern State of Hidalgo, Mexico. International Journal of Applied, 2 (8), 2012.

27. MUKHERJEE A., LAI R. Comparison of soil quality index using three methods. PloS one, 9 (8), e105981, 2014. 
28. PARRA-GONZALEZ S.D., RODDRIGUEZ-VALENZUELA J. Determination of the Soil Quality Index by Principal Component Analysis in Cocoa Agroforestry System in the Orinoco Region, Colombia. Journal of Agriculture and Ecology Research International, 10 (3), 1, 2017.

29. DATTA S., TAGHVAEIAN S., STIVERS J. Understanding Soil Water Content and Thresholds for Irrigation Management. Oklahoma Cooperative Extension Service, BAE-1537, 2017.

30. BUCHHOLZ D.D., BROWN J.R., GARRET J., HANSON R., WHEATON H. CROCKER D., LORY J., NATHAN M., SCHARF P. Soil test interpretations and recommendations handbook: University of Missouri-College of Agriculture, Division of Plant Sciences, USA, 39, 2004.

31. ALLEN S.E., GRIMSHAW H.M., PARKINSON J.A., QUARMBY C. Chemical analysis of ecological materials: Blackwell Scientific Publications, Oxford, UK, 1974.

32. GUIDE SQTK. Soil Quality Test Kit Guide. USDA Agricultural Research Service. National Consevation Service. Soil, 1999.

33. WHITMAN W.B., COLEMAN D.C., WIEBE W.J. Prokaryotes: the unseen majority. Proceedings of the National Academy of Sciences, 95 (12), 6578, 1998.

34. VAN ELSAS J.D., TREVORS J.T., JANSSON J.K., NANNIPIERI P. Modern soil microbiology. $2^{\text {nd }}$ Ed. : CRc Press, Boca Raton, 672, 2006.

35. ROLDDAN A., SALINAS-GARCIA J., ALGUACIL M., CARAVACA F. Changes in soil enzyme activity, fertility, aggregation and $\mathrm{C}$ sequestration mediated by conservation tillage practices and water regime in a maize field. Applied Soil Ecology, 30 (1), 11, 2005.

36. ADETUNJI A.T., LEWU F.B., MULIDZI R., NCUBE B. The biological activities of $\beta$-glucosidase, phosphatase and urease as soil quality indicators: a review. Journal of Soil Science and Plant Nutrition, 17 (3), 794, 2017.

37. BLONSKA E., JANUSZEK K. Usability of enzyme activity in estimation of forest soil quality. Folia Forestalia Polonica, Seria A-Forestry, 55 (1), 18, 2013.

38. YU X., LIU X., ZHU T. Walnut growth and soil quality after inoculating soil containing rock phosphate with phosphate-solubilizing bacteria. Sci Asia, 40, 21, 2014.

39. MEENA V., MAURYA B., VERMA R., MEENA R., JATAV G., MEENA S.K., MEENA S.K., MEENA S.K. Soil microbial population and selected enzyme activities as influenced by concentrate manure and inorganic fertilizer in alluvium soil of Varanasi. Bioscan, 8 (3), 931, 2013.

40. KANG H., KANG S., LEE D. Variations of soil enzyme activities in a temperate forest soil. Ecological Research, 24 (5), 1137, 2009.
41. TESFAHUNEGN G.B. Soil quality assessment strategies for evaluating soil degradation in Northern Ethiopia. Applied and Environmental Soil Science, 2014.

42. FERNANDES J.C., GAMERO C.A., RODRIGUES J.G.L., MIRAS-AVALOS J.M. Determination of the quality index of a Paleudult under sunflower culture and different management systems. Soil and Tillage Research, 112 (2), 167, 2011.

43. ASKARI M.S., HOLDEN N.M. Indices for quantitative evaluation of soil quality under grassland management. Geoderma, 230, 131, 2014.

44. SUPRIYADI S., PURWANTO P., SARIJAN A., MEKIUW Y., USTIATIK R., PRAHESTI, R.R. The Assessment of soil quality at Paddy fields in Merauke, Indonesia. Bulgarian Journal of Agricultural Science, 23 (3), 443, 2017.

45. DALSHAD A.D., PAKHSHAN M.M., SHIREEN A.A. Effect of phosphorus fertilizers on growth and physiological phosphorus use efficiency of three soy bean cultivars. Journal of Verterinary and Agricultural Science, 3 (6), 32, 2013.

46. WALPODA B.C., YOON M-H. In vitro solubilization of inorganic phosphates by phosphate solubilizing microorganisms. African Journal of Microbiology Research, 7 (27), 3534, 2013.

47. ABROL I., YADAV J.S.P., MASSOUD F. Salt-affected soils and their management. FAO Soils Bulletin 39, Rome, FAO, 1988.

48. SIX J., BOSSUYT H., DEGRYZE S., DENEF K. A history of research on the link between (micro) aggregates, soil biota, and soil organic matter dynamics. Soil and Tillage Research, 79 (1), 7, 2004.

49. AKHTARUZZAMAN M., HAQUE M.E., OSMAN K.T. Morphological, physical and chemical characteristics of hill forest soils at Chittagong University, Bangladesh. Open Journal of Soil Science, 4 (1), 26, 2014.

50. VELMOUROUGANE K., VENUGOPALAN M., BHATTACHARYYA T., SARKAR D., Pal D., SAHU A. RAY S.K., NAIR K.M., PRASAD J. Soil dehydrogenase activity in agro-ecological sub regions of black soil regions in India. Geoderma, 197, 186, 2013.

51. LIN S., WANG S., SI Y., YANG W., ZHU S., NI, W. Variations in eco-enzymatic stoichiometric and microbial characteristics in paddy soil as affected by long-term integrated organic-inorganic fertilization. PloS one, 12, (12), e0189908, 2017.

52. PIOTROWSKA-DLUGOSZ A., WILCZEWSKI E. Soil Phosphatase Activity and Phosphorus Content as Influenced by Catch Crops Cultivated as Green Manure. Polish Journal of Environmental Studies, 23 (1), 2014. 
